\title{
New Techniques for Treating an Anal Fistula
}

\author{
Kee Ho Song \\ Department of Surgery, Daehang Hospital, Seoul, Korea
}

Surgery for an anal fistula may result in recurrence or impairment of continence. The ideal treatment for an anal fistula should be associated with low recurrence rates, minimal incontinence and good quality of life. Because of the risk of a change in continence with conventional techniques, sphincter-preserving techniques for the management complex anal fistulae have been evaluated. First, the anal fistula plug is made of lyophilized porcine intestinal submucosa. The anal fistula plug is expected to provide a collagen scaffold to promote tissue in growth and fistula healing. Another addition to the sphincter-preserving options is the ligation of intersphincteric fistula tract procedure. This technique is based on the concept of secure closure of the internal opening and concomitant removal of infected cryptoglandular tissue in the intersphincteric plane. Recently, cell therapy for an anal fistula has been described. Adipose-derived stem cells have two biologic properties, namely, ability to suppress inflammation and differentiation potential. These properties are useful for the regeneration or the repair of damaged tissues. This article discusses the rationales for, the estimated efficacies of, and the limitations of new sphincter-preserving techniques for the treatment of anal fistulae.

Keywords: Anal fistula; Rectal fistula; Fecal incontinence

\section{INTRODUCTION}

An anal fistula is a chronic phase of anorectal sepsis and is characterized by chronic purulent drainage or cyclical pain associated with abscess formation, followed by intermittent spontaneous decompression $[1,2]$. The goals in the treatment of an anal fistula are to eliminate the primary fistula opening, any associated tracts, and any secondary openings without a change in continence. Most anal fistulae are simple and can be treated using a fistulotomy, which has a low recurrence rate and an acceptable rate of morbidity [36]. However, the treatment of a complex anal fistula, which is defined as a fistula whose treatment poses an increased risk for a change in continence, still represent a challenge [7-9]. The recurrence rate for a complex anal fistula managed with a cutting seton is reported to be 0 to $8 \%$, with minor and major incontinence be-

Received: February 14, 2011 Revised: October 9, 2011

Accepted: November 8, 2011

Correspondence to: Kee Ho Song, M.D.

Department of Surgery, Daehang Hospital, 481-10 Bangbae 3-dong,

Seocho-gu, Seoul 137-820, Korea

Tel: +82-2-6388-8114, Fax: +82-2-6388-8115

E-mail: stowe2@naver.com

(C) 2012 The Korean Society of Coloproctology

This is an open-access article distributed under the terms of the Creative Commons Attribution NonCommercial License (http://creativecommons.org/licenses/by-nc/3.0) which permits unrestricted noncommercial use, distribution, and reproduction in any medium, provided the original work is properly cited. ing reported in 34 to $63 \%$ and 2 to $26 \%$ of patients, respectively [10-14]. Cutting seton is also associated with significant morbidity related to discomfort from the seton. Advancement flap is still considered to be the gold standard of treatment for a complex anal fistula. Successful healing of the fistula has been demonstrated in 55 to $98 \%$ of patients $[8,10,15-17]$. However, this procedure is technically demanding, and although the sphincter mechanism is not divided during advancement flap repair of the fistula, minor incontinence has been found in up to $31 \%$ patients and major incontinence in up to $12 \%$ of patients $[10,18,19]$.

Because of the risk of a change in continence with these conventional techniques, sphincter-preserving techniques for the management of complex anal fistulae have been evaluated. Initial studies of fibrin glue injection for the management of anal fistulae were promising. However, long-term results have been disappointing [20]. Glue was easy to apply, but probably not ideal for fistula treatment because of its liquid consistency. A failure of the formed glue clot in a properly sealed tract, the inability to securely fix the material within the tract and the uncertainty of tissue in growth into the glue may all explain the possible causes of the poor outcomes [21]. This article aims to review the literature and to identify the new sphincter-preserving techniques, such as the anal fistula plug, the ligation of intersphincteric fistula tract (LIFT) procedure and the cell therapy, used in the management of anal fistulae. 


\section{THE ANAL FISTULA PLUG}

The small intestinal submucosa is a natural biomaterial harvested from porcine small intestine and fabricated into a biomedical product of various shapes and thickness [22]. The fact that it has been demonstrably useful as a bioprosthetic material in infected fields makes its application in fistula surgery quite reasonable. The anal fistula plug has a biological configuration suitable for fistula disease (Fig. 1). The idea is to bridge the defect of the fistula with a biocompatible material that would act as a scaffold for the patient's own fibroblasts to come in and promote wound healing in the fistula tract $[23,24]$. The technique of plug deployment is as follows: The tract is explored, probed, and irrigated gently with hydrogen peroxide. Then, the apex of the plug is tied to the probe from the internal opening, and the plug is dragged through to the external opening. It is cut to fit and is secured in the internal opening by using a figure-of-eight suture, incorporating it with the mucosa of the anorectum to close the internal opening (Fig. 2) [25].

The anal fistula plug has been used in a number of cases with widely varying results (Table 1$)$ [21, 24, 26-33]. In an early prospec-

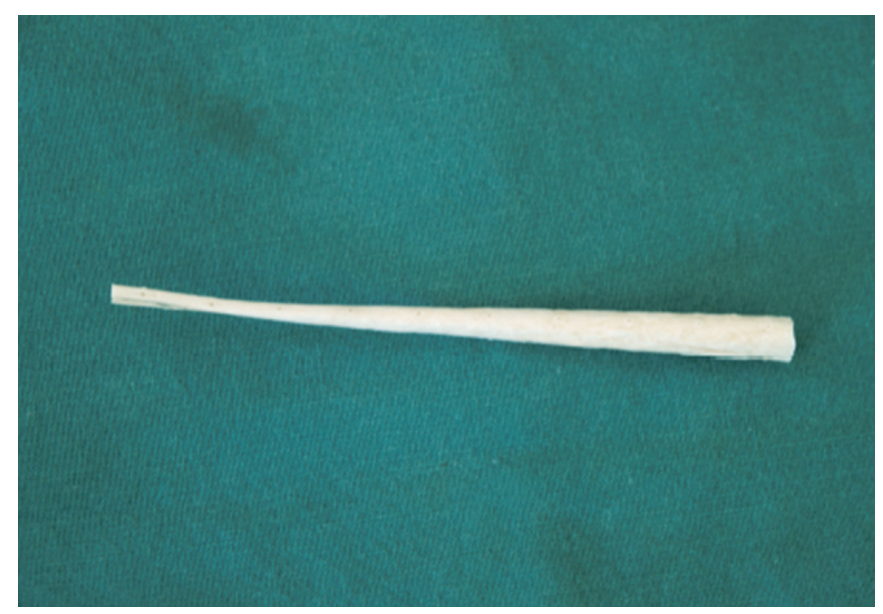

Fig. 1. Anal fistula plug.

tive series of 46 patients reported by Champagne et al. [26], after a median follow-up of 12 months (range, 6 to 24 months), 17\% of fistulae recurred. Johnson et al. [27] published a series comparing two prospective cohort groups of patients undergoing plug closure versus patients undergoing fibrin glue closure. They reported an $87 \%$ closure rate for the plug group versus a $40 \%$ closure rate for the glue group. Others have had less favorable results with fistula recurrence rates as high as $80 \%$ [21, 28-31]. On review of these publications, possible explanations for this discrepancy include differences in patient selection and technical problems. In an attempt to standardize the indications for use of the bioprosthetic anal fistula plug and techniques for its placement, a consensus conference was held in 2007. The group made a number of recommendations [22]. First, the group stressed that the use of the fistula plug could only be recommended for use in transsphincteric anal fistulae without acute inflammation or infection. The group felt that dislodgement of the anal fistula plug was a problem related to issues in the technique of plug placement. The group also stressed the importance of the external fistula opening being patent to allow for drainage.

Although most fistula recurrences occur within the first 3 months after treatment, a significant number of recurrences are known to

Table 1. Outcomes with the use of the anal fistula plug

\begin{tabular}{lcc}
\hline Author & Fistula healing, no. (\%) & Follow-up (mo) \\
\hline Champagne et al. [26] & $38 / 46(83)$ & 12 \\
Johnson et al. [27] & $13 / 15(87)$ & 3 \\
van Koperen et al. [28] & $7 / 17(41)$ & 7 \\
Garg [29] & $17 / 23(71)$ & 9 \\
Thekkinkattil et al. [30] & $19 / 43(44)$ & 11 \\
Ky et al. [31] & $24 / 45(55)$ & 6 \\
Christoforidis et al. [32] & $12 / 37(32)$ & 6 \\
Lawes et al. [21] & $4 / 17(24)$ & 7 \\
Ellis et al. [33] & $48 / 78(76)$ & $>12$ \\
Lenisa et al. [24] & $36 / 60(60)$ & 13.5 \\
\hline
\end{tabular}
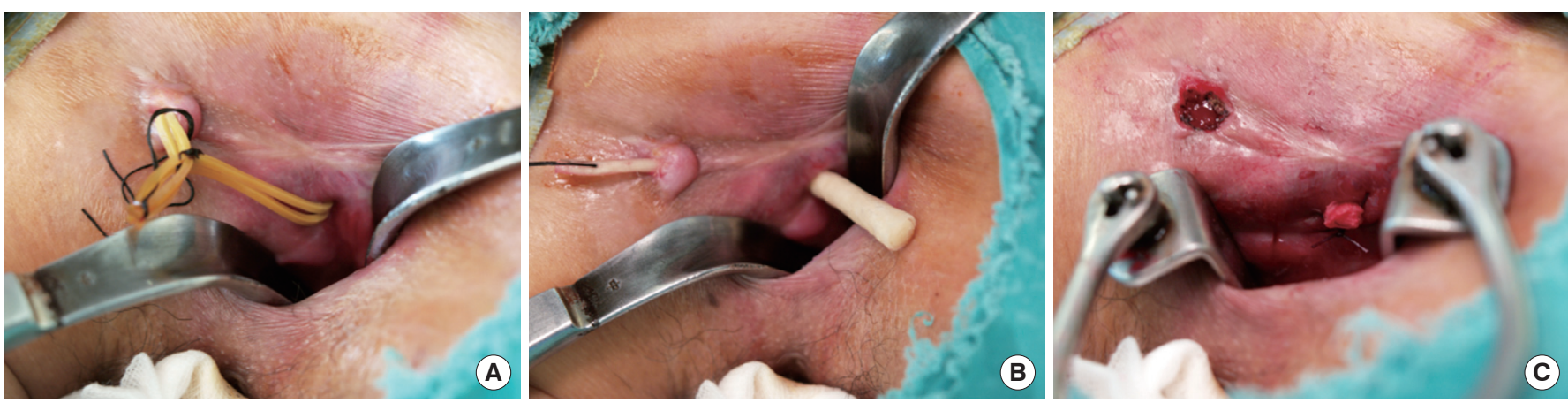

Fig. 2. Technical steps of anal fistula plug deployment: (A) identification of the fistula tract, (B) the plug being pulled through the internal opening until it is seated, and $(\mathrm{C})$ the plug being secured in the internal opening by using a figure-of-eight suture. 
Volume 28, Number 1, 2012

occur after this time. A minimum one-year follow-up is generally accepted as being needed to justify the results of sphincter-preserving surgery. Ellis et al. [33] reported that posterior fistula location, tobacco smoking, and a history of previous failure of the plug were independent predictors of plug failure.

The main limitation of application of the anal fistula plug in the treatment of anal fistulae in Korea is the high cost. In Korea, the cost of an anal fistula plug is not reimbursed by the national insurance system. Therefore, the cost of using a plug must be paid by the patients themselves. The other limitation of the anal fistula plug is the restrictive indication. It is interesting to note that the anal fistula plug procedure would probably be suitable for a low transsphincteric fistula. In a study from the University of Minnesota [32], the only variable that correlated with treatment outcome was the amount of sphincter involved. The overall success rate was $31 \%$. However, it was $65 \%$ for fistulae that involved less than onethird of the sphincter and $22 \%$ for those involving two-thirds or more.

\section{LIFT PROCEDURE}

Recent reports from Chulalongkorn University, Bangkok, Thailand, have described a novel technique called LIFT for the treatment of anal fistulae. A success rate of $94.4 \%$ was reported in the treatment of 18 patients $[34,35]$. This technique prevents the entry of fecal material into the fistula tract and eliminates the formation of a septic nidus in the intersphincteric space to allow healing of the anal fistula. Detailed technical steps of the LIFT procedure are as follows (Fig. 3) [35]. The location of internal opening is identified by injection of hydrogen peroxide or water through the external opening or by gently probing the fistula tract. A 1.5 to $2.0 \mathrm{~cm}$ curvilinear incision is made at the intersphincteric groove overlying the fistula tract. The dissection is kept close to the external sphincter to avoid cutting through the internal sphincter and breach- ing the anal mucosa. After the intersphincteric tract has been identified and dissected out, the tract is ligated close to the internal sphincter. Secure ligation of the intersphincteric tract abutting the internal opening is the key to success. The tract next to the suture site is divided, and the rest of intersphincteric tract is excised. After removal of the correct fistulous tract has been confirmed, infected granulation tissues in the rest of the tract and cavity are thoroughly removed with curettage. The open defect at the external anal sphincter is sutured through the intersphincteric wound. Finally, the incision wound is closed loosely.

The LIFT procedure has been used in five case series with promising early results (Table 2) [34, 36-39]. Shanwani et al. [36] reported that primary healing was achieved in $82.2 \%$ of the 45 patients. Bleier et al. [37] reported that successful fistula closure was achieved in $57 \%$ of the 35 patients. No patient reported any subjective compromise in continence after the procedure. The advantages of the LIFT procedure may include preservation of the anal sphincter, minimal tissue injury, shorter healing time, and its being a procedure that is relatively easy to perform. Additionally, even if the fistula is not healed successfully, the LIFT procedure may convert a difficult-to-treat transsphincteric fistula into an easier-to-manage intersphincteric fistula.

Table 2. Outcomes with the ligation of intersphincteric fistula tract procedure

\begin{tabular}{lcccc}
\hline Author & No. & $\begin{array}{c}\text { Success } \\
(\%)\end{array}$ & $\begin{array}{c}\text { Inconti- } \\
\text { nence }\end{array}$ & $\begin{array}{c}\text { Mean } \\
\text { follow-up (mo) }\end{array}$ \\
\hline Rojanasakul et al. [34] & 18 & 94.0 & 0 & - \\
Shanwani et al. [36] & 45 & 82.2 & 0 & 9 \\
Bleier et al. [37] & 39 & 57.0 & 0 & 5 \\
Aboulian et al. [38] & 22 & 77.0 & 0 & $2-15$ \\
Tan et al. [39] & 55 & 76.4 & 0 & 24 \\
\hline
\end{tabular}
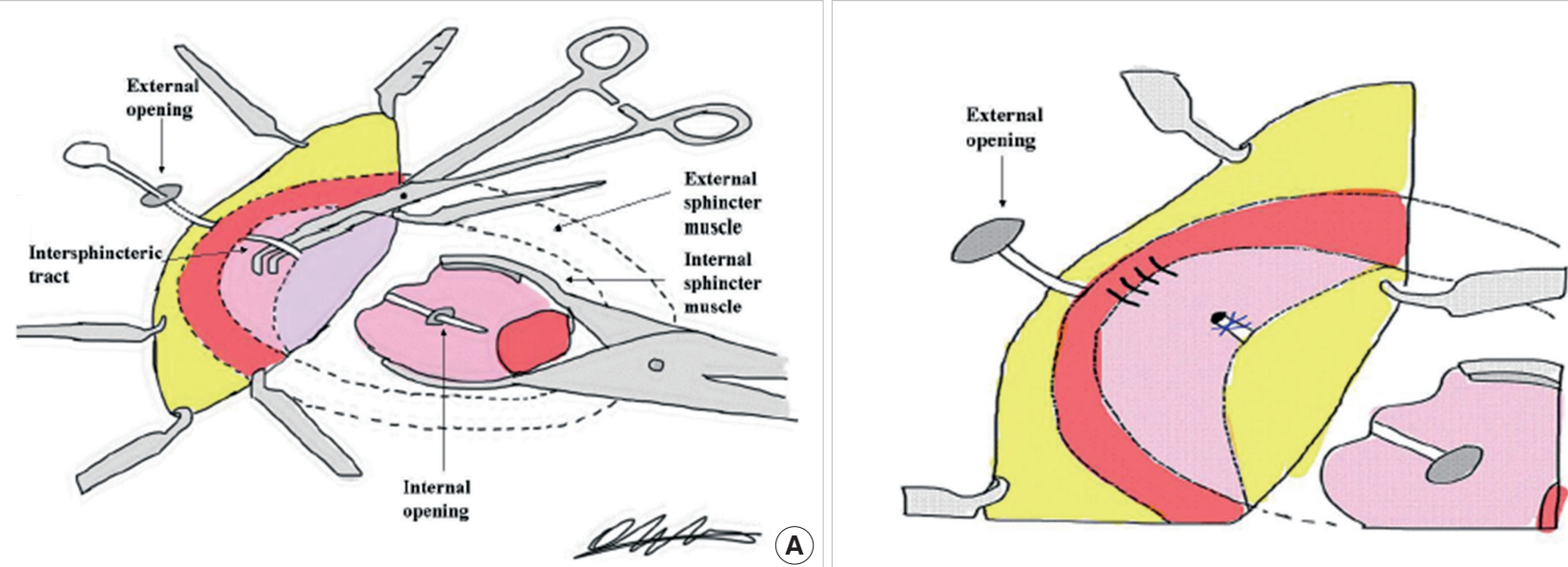

Fig. 3. Illustration of the ligation of intersphincteric fistula tract procedure. (A) After identification of the internal opening, the fistula tract is dissected free in the intersphincteric space. (B) The intersphincteric tract is ligated and divided. 
However, a number of questions remain unanswered. First, the published results are the only case series of a heterogeneous population, and the good results may come from selection bias. Second, there were some variations in the manner in which the fistula was ligated and in the coring out or curettage of the external tract. Third, a longer and objective follow-up would be a better indicator of the durability, and no standardized questionnaires were used pre- or postoperatively with respect to fecal incontinence and quality of life [37]. Additionally, as is the anal fistula plug, the indication for the LIFT procedure seems to be limited to the transsphincteric fistula. The LIFT procedure for a high transsphincteric or suprasphincteric fistula may be technically difficult. Interestingly, another intersphincteric approach for the treatment of a complex anal fistula has been described by Matos et al. [40]. Rojanasakul [35] reported two major differences between the LIFT and the previously described technique. First, the ligation of the fistula tract is more secure than over sewing, and second, removal of infected granulation tissue by curettage is more practical and less time-consuming than total excision of the tract and primary repair. Apart from the difficulty in the LIFT procedure for a high transsphincteric or a suprasphincteric fistula, the identification of the intersphincteric tract through the intersphincteric approach seems to require more advanced technical skills than the removal of the intersphincteric tract and infected granulation tissue in a conventional technique does.

\section{BIOLIFT PROCEDURE}

Neal Ellis [41] published outcomes with the BioLIFT technique for the management of transsphincteric fistulae. He reported that the success rate was $94 \%$ of 31 patients. The BioLIFT technique is a variation of the LIFT technique in which a bioprosthetic is placed in the intersphincteric plane to reinforce the closure of the fistula tract. The bioprosthetic graft acts as a physical barrier in the intersphincteric space. Actually, the BioLIFT technique utilized a transection of the intersphincteric tract and closure of the fistula opening in the internal sphincter, which is similar to the procedure described by Matos et al. [40], instead of ligating the intersphincteric tract. When compared to the LIFT, the BioLIFT technique has two potential disadvantages. First, it requires a more extensive dissection in the intersphincteric space because the bioprosthetic must overlap the closure of the fistula tract by at least 1 to $2 \mathrm{~cm}$ in all directions. The second disadvantage is the relatively high cost of the bioprosthetic materials.

\section{EXPANDED ADIPOSE-DERIVED STEM CELLS (ASCs)}

Mesenchymal adult stem cells extracted from certain tissues, such as adipose tissue, can differentiate into various types of cell [42]. Garcia-Olmo et al. $[43,44]$ chose adipose tissue as the source of stem cells because of their two biologic properties: their ability to suppress inflammation and their differentiation potential. Moreover, enough fat can be obtained with liposuction, and the fat cells can be harvested with minimal adverse effects on the patient. Their phase I clinical trials show that adipose-derived stem cells are safe for the treatment of a fistula in Crohn's disease [43], and they published a phase II multicenter, randomized controlled trial to further investigate the effectiveness and safety of ASCs in the treatment of complex anal fistulae compared with the fibrin glue group [44]. The treatment procedures are as follows: 1) tract identification, with special emphasis on the identification of the internal opening; 2) tract curettage, with special emphasis on the intersphincteric tract; 3) closure of the internal opening; 4) injection of a cell suspension through a long fine needle into the tract walls; 5) sealing of the tract with fibrin glue. They reported that fistula healing was observed in $71 \%$ of 24 patients who received ASCs in addition of fibrin glue compared with $16 \%$ of 25 patients who received fibrin glue alone (relative risk for healing, 4.43; confidence interval, 1.74 to $11.27 ; \mathrm{P}<0.001$ ). The proportion of patients with healing was similar between the Crohn's and the non-Crohn's subgroups.

An advantage of using stem cells to treat an anal fistula is that, because tract resection is not required, the treatment does not injure the anal sphincter (Fig. 4). There are, nonetheless, some limitations of the ASCs-based therapy. First, the cost of treatment with ASCs is difficult to evaluate in detail at present. Second, technically, secure closure of the internal opening and complete injection of the cell suspension over the tract may be complicated procedures. Finally, as yet, there are no reports on the long-term effects of using ASCs.

In the meantime, a pilot study on autologous fibroblast-based therapy for the treatment of anal fistulae is in progress in the United Kingdom [45]. In brief, the authors suggest that the addition of autologous fibroblasts to the filling material (collage paste) provides the best histologic healing.

\section{CONCLUSION}

To the colorectal surgeon, the complex anal fistula remains a challenging condition to manage despite the best of technologic ad-
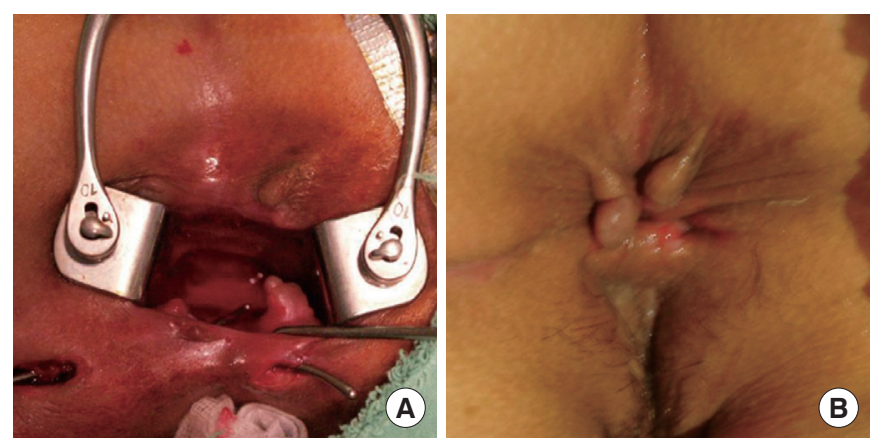

Fig. 4. Fistula (A) before and (B) eight weeks after the injection of adipose-derived stem cells. 
vances. Therefore, the colorectal surgeon should become familiar with various new techniques for treating an anal fistula and remember that conventional fistula surgery, such as cutting seton and advancement flap, has an important role. Especially, the advancement flap is still the gold standard of treatment for complex anal fistulae. Definitive evidence of the advantage of the new sphincter-preserving techniques compared with the traditional intervention requires randomized control studies, which are now being conducted.

\section{CONFLICT OF INTEREST}

No potential conflict of interest relevant to this article was reported.

\section{REFERENCES}

1. Han KS, Cho HM, Kim DH, Kim JG. Retrospective analysis of a fistula-in-ano: focus on an anal-sphincter-preserving procedure. J Korean Soc Coloproctol 2007;23:403-9.

2. Whiteford MH, Kilkenny J 3rd, Hyman N, Buie WD, Cohen J, Orsay C, et al. Practice parameters for the treatment of perianal abscess and fistula-in-ano (revised). Dis Colon Rectum 2005;48: 1337-42.

3. Lim SW. Surgery in an intersphincteric fistula. J Korean Soc Coloproctol 2009;25:365-71.

4. Kronborg O. To lay open or excise a fistula-in-ano: a randomized trial. Br J Surg 1985;72:970.

5. Vasilevsky CA, Gordon PH. The incidence of recurrent abscesses or fistula-in-ano following anorectal suppuration. Dis Colon Rectum 1984;27:126-30.

6. van Tets WF, Kuijpers HC. Continence disorders after anal fistulotomy. Dis Colon Rectum 1994;37:1194-7.

7. Hwang SH, Bang MJ. Surgery for a complex anal fistula. J Korean Soc Coloproctol 2008;24:77-82.

8. Parks AG, Stitz RW. The treatment of high fistula-in-ano. Dis Colon Rectum 1976;19:487-99.

9. Kodner IJ, Mazor A, Shemesh EI, Fry RD, Fleshman JW, Birnbaum EH. Endorectal advancement flap repair of rectovaginal and other complicated anorectal fistulas. Surgery 1993;114:682-9.

10. Mizrahi N, Wexner SD, Zmora O, Da Silva G, Efron J, Weiss EG, et al. Endorectal advancement flap: are there predictors of failure? Dis Colon Rectum 2002;45:1616-21.

11. García-Aguilar J, Belmonte C, Wong DW, Goldberg SM, Madoff $\mathrm{RD}$. Cutting seton versus two-stage seton fistulotomy in the surgical management of high anal fistula. Br J Surg 1998;85:243-5.

12. Williams JG, MacLeod CA, Rothenberger DA, Goldberg SM. Seton treatment of high anal fistulae. Br J Surg 1991;78:1159-61.

13. Pearl RK, Andrews JR, Orsay CP, Weisman RI, Prasad ML, Nelson RL, et al. Role of the seton in the management of anorectal fistulas. Dis Colon Rectum 1993;36:573-7.

14. Hämäläinen KP, Sainio AP. Cutting seton for anal fistulas: high risk of minor control defects. Dis Colon Rectum 1997;40:1443-6.
15. Zimmerman DD, Briel JW, Gosselink MP, Schouten WR. Anocutaneous advancement flap repair of transsphincteric fistulas. Dis Colon Rectum 2001;44:1474-80.

16. Sonoda T, Hull T, Piedmonte MR, Fazio VW. Outcomes of primary repair of anorectal and rectovaginal fistulas using the endorectal advancement flap. Dis Colon Rectum 2002;45:1622-8.

17. Zimmerman DD, Delemarre JB, Gosselink MP, Hop WC, Briel JW, Schouten WR. Smoking affects the outcome of transanal mucosal advancement flap repair of trans-sphincteric fistulas. Br J Surg 2003;90:351-4.

18. Gustafsson UM, Graf W. Excision of anal fistula with closure of the internal opening: functional and manometric results. Dis Colon Rectum 2002;45:1672-8.

19. Kreis ME, Jehle EC, Ohlemann M, Becker HD, Starlinger MJ. Functional results after transanal rectal advancement flap repair of trans-sphincteric fistula. Br J Surg 1998;85:240-2.

20. Loungnarath R, Dietz DW, Mutch MG, Birnbaum EH, Kodner IJ, Fleshman JW. Fibrin glue treatment of complex anal fistulas has low success rate. Dis Colon Rectum 2004;47:432-6.

21. Lawes DA, Efron JE, Abbas M, Heppell J, Young-Fadok TM. Early experience with the bioabsorbable anal fistula plug. World J Surg 2008;32:1157-9.

22. Corman ML, Abcarian H, Bailey HR, Birnbaum EH, Champagne BJ, Cintron JR, et al. The surgisis((R)) AFP((TM)) anal fistula plug: report of a consensus conference. Colorectal Dis 2008;10: 17-20.

23. Christoforidis D, Etzioni DA, Goldberg SM, Madoff RD, Mellgren A. Treatment of complex anal fistulas with the collagen fistula plug. Dis Colon Rectum 2008;51:1482-7.

24. Lenisa L, Espìn-Basany E, Rusconi A, Mascheroni L, Escoll-Rufino J, Lozoya-Trujillo R, et al. Anal fistula plug is a valid alternative option for the treatment of complex anal fistula in the long term. Int J Colorectal Dis 2010;25:1487-93.

25. Deeba S, Aziz O, Sains PS, Darzi A. Fistula-in-ano: advances in treatment. Am J Surg 2008;196:95-9.

26. Champagne BJ, O'Connor LM, Ferguson M, Orangio GR, Schertzer ME, Armstrong DN. Efficacy of anal fistula plug in closure of cryptoglandular fistulas: long-term follow-up. Dis Colon Rectum 2006;49:1817-21.

27. Johnson EK, Gaw JU, Armstrong DN. Efficacy of anal fistula plug vs. fibrin glue in closure of anorectal fistulas. Dis Colon Rectum 2006;49:371-6.

28. van Koperen PJ, D’Hoore A, Wolthuis AM, Bemelman WA, Slors JF. Anal fistula plug for closure of difficult anorectal fistula: a prospective study. Dis Colon Rectum 2007;50:2168-72.

29. Garg P. To determine the efficacy of anal fistula plug in the treatment of high fistula-in-ano: an initial experience. Colorectal Dis 2009;11:588-91.

30. Thekkinkattil DK, Botterill I, Ambrose NS, Lundby L, Sagar PM, Buntzen S, et al. Efficacy of the anal fistula plug in complex anorectal fistulae. Colorectal Dis 2009;11:584-7.

31. Ky AJ, Sylla P, Steinhagen R, Steinhagen E, Khaitov S, Ly EK. Col- 
lagen fistula plug for the treatment of anal fistulas. Dis Colon Rectum 2008;51:838-43.

32. Christoforidis D, Pieh MC, Madoff RD, Mellgren AF. Treatment of transsphincteric anal fistulas by endorectal advancement flap or collagen fistula plug: a comparative study. Dis Colon Rectum 2009;52:18-22.

33. Ellis CN, Rostas JW, Greiner FG. Long-term outcomes with the use of bioprosthetic plugs for the management of complex anal fistulas. Dis Colon Rectum 2010;53:798-802.

34. Rojanasakul A, Pattanaarun J, Sahakitrungruang C, Tantiphlachiva $\mathrm{K}$. Total anal sphincter saving technique for fistula-in-ano; the ligation of intersphincteric fistula tract. J Med Assoc Thai 2007; 90:581-6.

35. Rojanasakul A. LIFT procedure: a simplified technique for fistulain-ano. Tech Coloproctol 2009;13:237-40.

36. Shanwani A, Nor AM, Amri N. Ligation of the intersphincteric fistula tract (LIFT): a sphincter-saving technique for fistula-in-ano. Dis Colon Rectum 2010;53:39-42.

37. Bleier JI, Moloo H, Goldberg SM. Ligation of the intersphincteric fistula tract: an effective new technique for complex fistulas. Dis Colon Rectum 2010;53:43-6.

38. Aboulian A, Kaji A, Kumar R. Early results of ligation of intersphincteric fitula tract for fistula-in-ano [abstract]. In: 2010 ASCRS Annual Meeting; 2010 May 15-19; Minneapolis, MN, USA. Arlington Heights, IL; American Society of Colon and Rectal Surgeons; 2010;138.
39. Tan K, Tan I, Koh DC, Tsang C. Long-term results of ligation of intersphincteric fistula tract (LIFT) technique in the management of anal fistula [abstract]. In: 2010 ASCRS Annual Meeting; 2010 May 15-19; Minneapolis, MN, USA. Arlington Heights, IL; American Society of Colon and Rectal Surgeons; 2010;155.

40. Matos D, Lunniss PJ, Phillips RK. Total sphincter conservation in high fistula in ano: results of a new approach. Br J Surg 1993;80: 802-4.

41. Neal Ellis C. Outcomes with the use of bioprosthetic grafts to reinforce the ligation of the intersphincteric fistula tract (BioLIFT procedure) for the management of complex anal fistulas. Dis Colon Rectum 2010;53:1361-4.

42. Mizuno H, Zuk PA, Zhu M, Lorenz HP, Benhaim P, Hedrick MH. Myogenic differentiation by human processed lipoaspirate cells. Plast Reconstr Surg 2002;109:199-209.

43. García-Olmo D, García-Arranz M, Herreros D, Pascual I, Peiro C, Rodríguez-Montes JA. A phase I clinical trial of the treatment of Crohn's fistula by adipose mesenchymal stem cell transplantation. Dis Colon Rectum 2005;48:1416-23.

44. Garcia-Olmo D, Herreros D, Pascual I, Pascual JA, Del-Valle E, Zorrilla J, et al. Expanded adipose-derived stem cells for the treatment of complex perianal fistula: a phase II clinical trial. Dis Colon Rectum 2009;52:79-86.

45. Himpson RC, Cohen CR, Sibbons P, Phillips RK. An experimentally successful new sphincter-conserving treatment for anal fistula. Dis Colon Rectum 2009;52:602-8. 